\title{
Concentration of Trace Elements in Raptors from Three Regions of Slovakia, Central Europe
}

\author{
Zuzana Hurníková1, Petronela Komorová2 ${ }^{2}$ Peter Šalamún ${ }^{1}$, Dana Miklisová1, \\ Gabriela Chovancová ${ }^{3}$, Martina Miterpáková ${ }^{1 *}$ \\ ${ }^{1}$ Institute of Parasitology, Slovak Academy of Sciences, Hlinkova 3, 04001 Košice, Slovakia \\ ${ }^{2}$ University of Veterinary Medicine and Pharmacy in Košice, Komenského 73, 04001 Košice, Slovakia \\ ${ }^{3}$ Research Centre and Museum of the Tatra National Park, 05906 Tatranská Lomnica, Slovakia
}

Received: 30 November 2020

Accepted: 14 May 2021

\begin{abstract}
Slovakia situated in the territory of Central Europe has a rich mining and industrial history with a strong pollutive impact on the environment, with heavy metals and metalloids as the most often analysed pollutants. Despite a relatively advanced toxic elements research, none enquiry has been performed in birds of prey, the most suitable bioindicators, in Slovakia yet. Regarding the lack of information, the presented study represents the first integrated results of the contamination status of raptor species with selected trace elements (arsenic, cadmium, chromium, copper, mercury, manganese and lead). In all, livers and muscles of 80 individuals across twelve species were collected and analysed using atomic absorption spectroscopy. Within the study, copper was the element detected with the highest concentrations, in several individuals overlapping the toxic threshold. Additionally, the results disclosed high hepatic lead concentrations, pointed to the probability of acute poisoning through lead shot ingestions, in three birds of prey. Subsequent comparative analyses revealed significantly higher concentrations of mercury in surveyed Spiš and Tatry region when compared with the other two sampling regions. Also, the highest average and median values concerning liver concentrations of cadmium and manganese and muscle concentrations of chromium were measured in samples originated from this region. The whole territory of the Spiš and Tatry region is covered by national parks and protected areas, and several European Important Bird Areas occurred there. Together with rich mining and smelting history and also the existence of natural geochemical anomalies, toxic elements biomonitoring should be continued in this area.

Finally, it can be concluded that the first oriented research in Slovakia showed that the concentration of monitored metals in the liver and muscles of birds of prey did not exceed the established tolerable
\end{abstract}

*e-mail:miterpak@saske.sk 
levels, except for copper, cadmium, and lead, for which concentrations exceeding defined toxic thresholds were occasionally found and cases of intoxication them with were reported.

Keywords: heavy metals, trace elements, raptors, pollution, bioindicators

\section{Introduction}

The environmental contamination with toxic elements, especially heavy metals and metalloids, is mainly caused by anthropogenic activities, expanding chemical industry and technical advances, but also by natural phenomena such as weathering or volcanic eruptions. However, it is estimated that at least 60 out of 118 naturally occurring elements were introduced into biogeochemical cycles on a larger scale as the results of human activity rather than natural causes [1].

The territory of Slovakia is characterised by numerous metal ore deposits and accordingly by a rich mining history that has flown into the formation of many heavy metal loaded habitats. Primary trace elements habitats are created especially at ore bodies and veins, secondary heavy metal enriched habitats are formed from mine heaps, slag wastes and in the surroundings of smelters [2].

According to geological researches, mankind currently witnesses the sixth species extinction which is accompanied not only by climate change but also by anthropogenic emission of mercury and other heavy metals [3]. The potential impact of accumulated toxic elements on humans and animals health could be monitored through the sentinel organism, especially birds that are in a majority of developed EU countries most commonly reported as victims of the poisoning. Above all, birds of prey, usually standing at the top of the food chain, long-lived, territorial, and with wellknown biology, are the most convenient indicators of environmental pollution $[4,5]$.

In Slovakia, 40 Important Bird Areas (IBA) have been identified, of which 39 have been proposed to be designated a Special Protection Area (SPA). The total area of all 40 IBAs is $13840.85 \mathrm{~km}^{2}$, which makes $28.2 \%$ of the area of Slovakia. The largest IBA, covered $1280 \mathrm{~km}^{2}$, is situated in the Volovské Vrchy Mountains belonging to the Slovenské Rudohorie Mountains on the border of Gemer and Spiš regions [6]. Both regions were included as sampling areas in the here presented study. In this area, several raptors species, in particular owls, are regularly observed, including Ural owl (Strix uralensis), tawny owl (Strix aluco) and eagle owl (Bubo bubo). In our study, strigiform birds with nocturnal activity are represented by four species: long-eared owl (Asio otus), eagle owl, tawny owl and Ural owl. So far, 12 species of nocturnal raptors owls have been recorded in Slovakia, 10 of which are breeders. The most frequently occurring species are the long-eared owl and tawny owl with more than 2500 breeding pairs, followed by the Ural owl with
$1400-2500$ breeding pairs and of eagle owl with only 300-400 pairs recorded [7]. Other significant IBAs are situated in the lowland area of the south-eastern part of Slovakia in Dolný Zemplín, the region also included in our study as a sampling locality. It is the most important breeding and migrating site for waterbirds in Slovakia. Additionally, in this area the largest national population of the imperial eagle (Aquila heliaca) is inhabited [6]. Regarding diurnal raptor species, 33 of them have been recorded in Slovak territory so far. Eighteen of them are regular breeders and only eight species including northern goshawk (Accipiter gentilis), common buzzard (Buteo buteo), common kestrel (Falco tinnucullus) and imperial eagle (A. heliaca) listed in our set of samples are breeding residents. The rest of the raptor species examined within our study, concretely long-legged buzzard (Buteo rufinus) and rough-legged buzzard (Buteo lagopus), are migrants, either visiting Slovakia during the breeding season or just occurring on migration [7]. A. heliaca together with saker falcon (Falcon cherrug) are the most endangered raptor species not only in Slovakia but also worldwide. In the territory of Slovakia about 40 nestling couples of both species have been observed. The main threatening factors of these species represent electrocution, bird crimes including poisoning and illegal shooting, disturbance and logging in breeding territories, loss and degradation of breeding and feeding habitats [7]. Common buzzard, Buteo buteo, was the most prevalent species examined within our study. It is the most common raptor species not only in Slovakia but also in Europe. In Slovakia, it nests in different types of habitats except for areas with an altitude over $1300 \mathrm{~m}$. The number of breeding pairs varies between 5000 and 7000 [7, 8]. Two relative species, B. rufinus and B. lagopus, are considered wintering species, but in the context of global climate changes it is assumed that B. rufinus could also nest in the territory of Slovakia. Small rodents predominate in the food of Buteo species and the size of their population influences also buzzards' abundance during the individual years [8]. The second most numerous species of birds of prey in Slovakia, with a count of 5 000-7 000 breeding pairs, is the common kestrel (Falco tinnunculus) widely distributed in the whole territory. The other two species of falconiformes, Eurasian hobby (F. subbuteo) and saker falcon (F. cherrug) are much less abundant with around 600 and 40 nesting pairs. Whereas $F$. subbuteo occurred in all Slovak regions, F. cherrug inhabited only southern areas [7, 8]. The last of the species examined in our study, northern goshawk (Accipiter gentilis) is also a relatively common bird of prey nesting in Slovakia, 
but its abundance is declining. It mainly preys on birds and it is considered the most important regulator of corvids. In the past it was significantly hunted, it is also harmed by forestry activities and chemization of the environment [8].

However, despite being the most suitable biomonitors and sentinels of environmental contamination, birds of prey are strictly protected in many European countries and sample collection can be quite difficult. Concretely, in Slovakia, despite relatively advanced heavy metals biomonitoring and research, none enquiry has been performed in raptors. Regarding the lack of information from this geographic region, the aim of our study was to obtain the first integrated results of contamination status of several birds of prey with selected trace elements, arsenic (As), cadmium (Cd), chromium $(\mathrm{Cr})$, copper $(\mathrm{Cu})$, mercury $(\mathrm{Hg})$, manganese $(\mathrm{Mn})$ and lead $(\mathrm{Pb})$, and to determine its dependency on sampling regions with their environmental peculiarities.

\section{Material and Methods}

\section{Sample Collection and Preparation}

A total of 80 individuals across twelve species of birds of prey were collected during the study. Five species ranged to the orders Accipitiformes [Accipiter gentilis $(\mathrm{n}=2)$, Aquila heliaca $(\mathrm{n}=4)$, Buteo buteo $(\mathrm{n}=47)$, Buteo lagopus $(\mathrm{n}=3)$, Buteo rufinus $(\mathrm{n}=3)]$, three to the Falconiformes: [Falco cherrug $(\mathrm{n}=1)$, Falco subbuteo $(\mathrm{n}=2)$, Falco tinnunculus $(\mathrm{n}=2)]$, and four species were classified to the order Strigiformes [Asio otus $(\mathrm{n}=3)$, Bubo bubo $(\mathrm{n}=2)$, Strix aluco $(\mathrm{n}=1)$, Strix uralensis $(\mathrm{n}=10)]$. All birds integrated into the study were free-living and died naturally or as a result of injury or disease. Found carcasses were referring to several state organisations (Raptor Protection of Slovakia, Museum of the Tatra National Park, Clinic for birds and exotic animals of the University of veterinary medicine and pharmacy in Košice, Rehabilitation station in ZOO Bojnice, Košice Airport Bioprotection, State Nature Conservancy of the Slovak Republic-Slovenský kras National Park, Slovenský raj National Park, Pieniny National Park, Regional Conservation Centre in Prešov and Vihorlat protected area) and consequently submitted at Institute of Parasitology SAS for examination.

During the autopsy, from each cadaver, the liver and muscle tissues from the musculus pectoralis were taken and stored separately in plastic bags at $-20^{\circ} \mathrm{C}$ till further analyses.

\section{Sampling Areas}

The majority of the examined animals were collected on the territory of different districts in the eastern part of Slovakia. For results interpretation 73 from 80 examined individuals were categorized into three different regions according to their origin: 38 were included to Region I (Abov and Gemer with districts Košice and Rožňava), 15 fell into Region II (Dolný Zemplín including districts Trebišov, Michalovce, and Sobrance) and 20 individuals came from Region III (Spiš and Tatry with districts Spišská Nová Ves, Stará L’ubovňa, Kežmarok, Poprad and Liptovský Mikuláš) (Fig. 1). The remaining seven birds of prey were originated in other parts of Slovakia and were not geographically analyzed but were included in the analysis related to species.

Region I includes two informal regions, the Abov and Gemer situated in the south of eastern Slovakia. The Abov region lies in the municipality of Košice, the second largest city of Slovakia, and its surroundings. The core of the Abov region is the L-shaped Košická kotlina basine surrounded by Slanské Vrchy Mountains, Volovské Vrchy Mountains, and the south-western part of the region is bounded by karstic landscape with plateaux of Slovak Karst [9]. In Košice, the main source of environmental pollution represents an old residue of long-term magnesite industry and metallurgy in the U.S. Steel Company [10]. District Rožňava located in Gemer region is situated to the west from Košice between the slopes of the Slovenské Rudohorie Mountains and National Park of Slovak Karst. It is a large forested mountain area with prevailing beech forests in the eastern parts and the spruce forests in the west. Due to their location in the Carpathian Mountains close to warmer lowlands, there are a high variety and richness of bird species. The territory is characterized by the 700-old mining history of gold, silver, and iron.

Region II, Dolný Zemplín, is situated in the southeastern part of Slovakia and it is bound to Ukraine in the east and Hungary in the south. The large part of the region is covered by Eastern Slovak Lowland, the second-largest lowland in Slovakia with an area of 4000 square kilometers, which comprises rivers, canals, marshes, wet meadows, floodplain forests, and abandoned agricultural land. This area is considered the most important breeding and migrating site for waterbirds in Slovakia. Dolný Zemplín is a mainly rural region, in the districts Michalovce and Trebišov most of the agricultural production is concentrated [9]. From an environmental point of view, Vojany thermal power station, a major source of fly ash in Slovakia, is situated in the south of this region [10].

Region III for the purpose of our study represents an informal historical regions Spiš and Tatry neighbouring Poland in the north and bounded with river Váh in the west and Slovenské Rudohorie Mountains in the south. The core of the Spiš region is formed by the basins of the rivers Hornád and Poprad. More than $40 \%$ of the region territory is covered by forests [9]. In the past, the Spiš region was characterized by the strongly developed mining activities and long-termed production of copper, mercury, manganese, lead, and zinc [10]. Nowadays, 

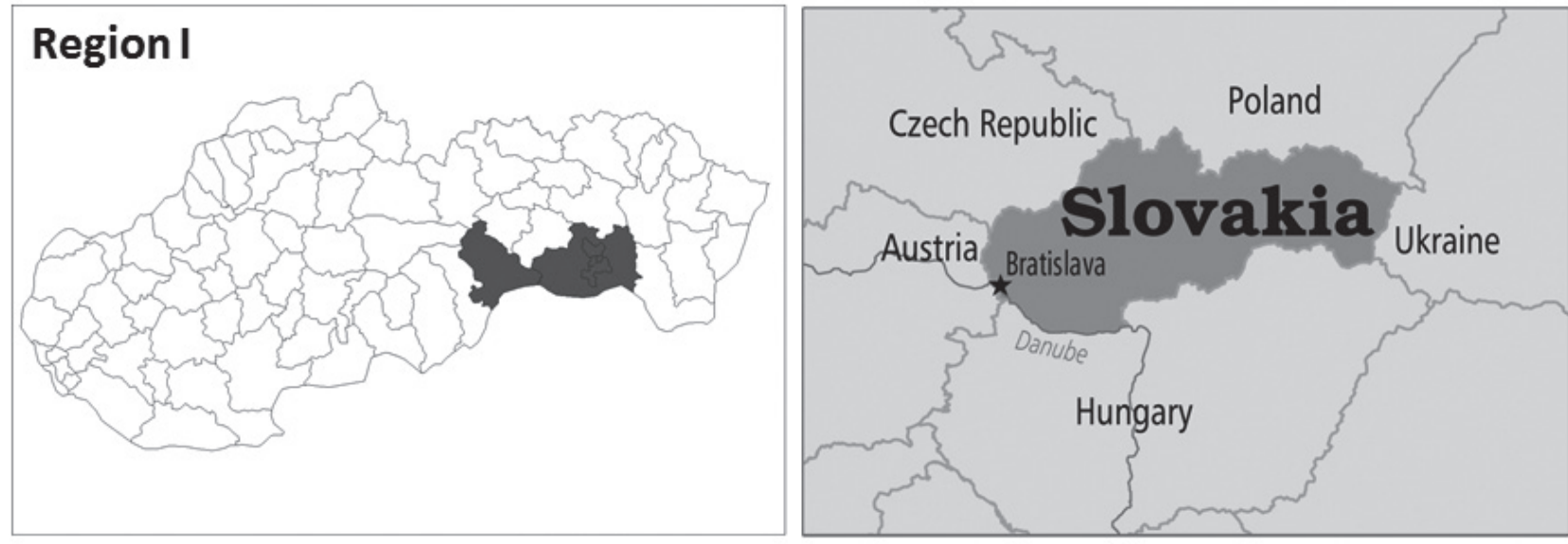

\section{Region II}
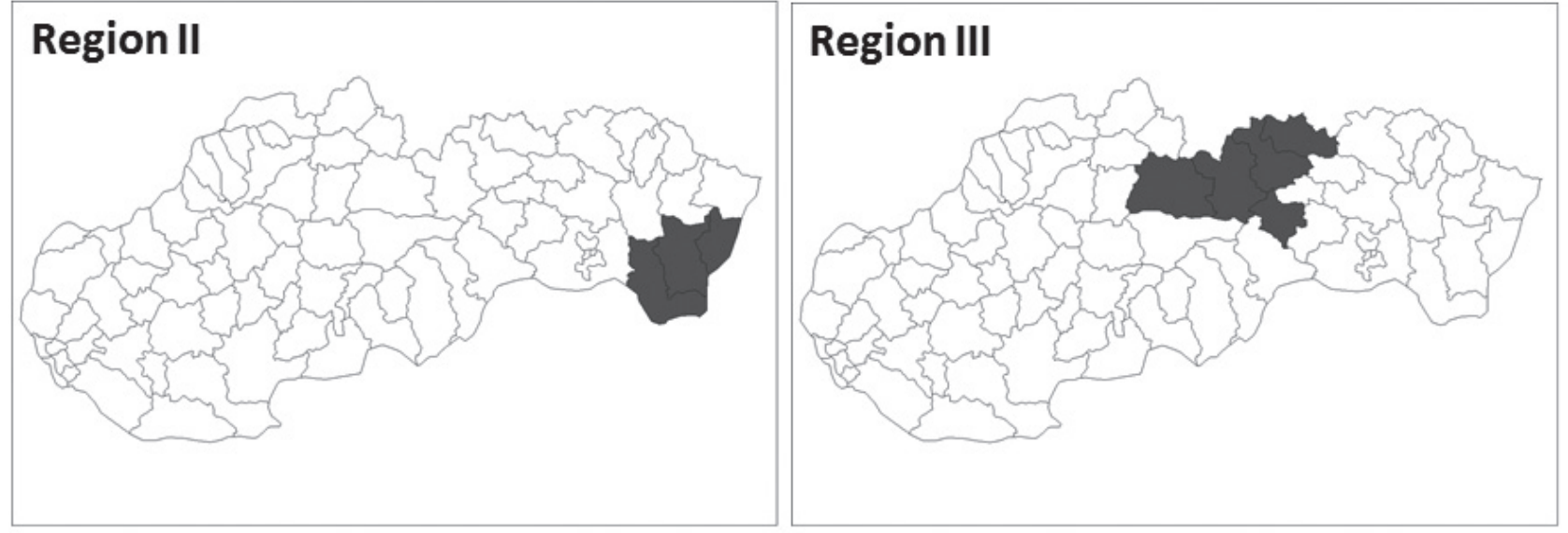

Fig. 1. Sampling areas of examined raptors species. Region I (Abov and Gemer); Region II (Dolný Zemplín); Region III (Spiš and Tatry).

Tatry and Spiš are mainly tourist regions with three national parks situated on their territories.

According to environmental regionalization of Slovakia (ERS) conducted on information on the status of the environment in the SR over the last 20 years, Slovak territory is divided into three types of environmental quality. Regarding sampling regions, only Tatry area from Region III was classified as a region of $1^{\text {st }}$ environmental quality (regions with the non-disturbed environment). On the other hand, Spiš area from the same sampling region was included to the $2^{\text {nd }}$ environmental quality (regions with the moderately disturbed environment) with several zones (e.g Slovenské Rudohorie Mountains) ranked as regions of $3^{\text {rd }}$ environmental quality (regions with the heavily disturbed environment). All districts from Region I (Abov and Gemer) and Region II (Dolný Zemplín) were included in the $2^{\text {nd }}$ or $3^{\text {rd }}$ environmental quality [11].

\section{Samples Analyses}

In the frame of the present study, liver and muscle tissues from birds of prey were analysed for seven trace elements (arsenic - As, cadmium - $\mathrm{Cd}$, chromium - $\mathrm{Cr}$, copper - $\mathrm{Cu}$, mercury - Hg, manganese - Mn and lead $-\mathrm{Pb})$.
Each sample (0.5-1.0 g) was digested in a Microwave Digestion System Ethos 1 (Milestone S.r.1.) using 30\% hydrogen peroxide and $65 \%$ nitric acid (Suprapur, Merck) in a 1:7 v/v. The digestion was held for 30 minutes, where the maximum temperature $200^{\circ} \mathrm{C}$ was reached in 15 minutes and was held to the end of the program next 15 minutes. After the digestion, samples were diluted with ultra-pure water (Milli-Q, Merck) and analysed for the elements concentration using electrothermal atomic absorption spectrophotometer (ZEEnit 700P, Analytik Jena AG). For detection of mercury concentration hydride generation atomic absorption spectroscopy was used (ZEEnit 700P, Analytik Jena AG).

Along with samples following Certified Reference Materials (CRM) were prepared to ensure the validity and accuracy of the analysis. For liver samples as CRM was used Bovine Liver BCR - 185R (European Commission - Joint Research Centre, Institute for Reference Materials and Measurements), and for muscle samples as CRM Chicken Meat GBW10018 (Institute of Geophysical and Geochemical Exploration, Langfang, China) was used. All concentrations of monitored elements are expressed in ppb (parts per billion; ng/g) on a wet weight basis (ww). In discussion, when comparing our data with the data expressed per dry weight basis (dw), we used a conversion factor of 
3.0 for both liver and muscle to calculate the corresponding concentrations according to recommendation [12].

The data obtained within the study were put through descriptive statistical analyses. Data from all elements analysed except As in muscle are included in Table 1. It is since all arsenic values in muscle are below the limit of detection (LOD). Data for $\mathrm{Cu}$ and $\mathrm{Mn}$ for both organs, $\mathrm{Cr}$ for muscle, $\mathrm{Hg}$ for muscle only in region III and $\mathrm{Cd}$ for liver were without non-detects. The rest of the data includes both detected and non-detected values, (so-called censored data) and must be analyzed concerning the amount of data below the detection limits. If non-detects were recorded between under $50 \%$, non-detects were replaced with 0 and Aitchison's method was used for mean and variance calculation. In the rest of the censored data with clearly more than $50 \%$ non-detects, the only number of non-detects, median, and range of data are presented. Guidelines of the Environmental Protection Agency were used [13].

Table 1. Trace elements concentrations (ng/g; ppb ww) in livers and muscles of examined birds of prey in three different regions of Slovakia. If more than $50 \%$ non-detects, only number of non-detects, median and range of data are presented. Limit of detection (LOD) for each elements measured in liver and muscle.

\begin{tabular}{|c|c|c|c|c|c|c|c|c|}
\hline & \multicolumn{2}{|c|}{$\begin{array}{l}\text { Region I } \\
(\mathrm{n}=38)\end{array}$} & \multicolumn{2}{|c|}{$\begin{array}{c}\text { Region II } \\
(\mathrm{n}=15)\end{array}$} & \multicolumn{2}{|c|}{$\begin{array}{c}\text { Region III } \\
(\mathrm{n}=20)\end{array}$} & \multicolumn{2}{|c|}{ LOD (ng/g) } \\
\hline & Liver & Muscle & Liver & Muscle & Liver & Muscle & Liver & Muscle \\
\hline \multicolumn{7}{|c|}{ As } & \multirow{4}{*}{5.052} & \multirow{4}{*}{5.967} \\
\hline Number of detects & 3 & - & 1 & - & 1 & - & & \\
\hline Median & $\mathrm{Nd}$ & - & $\mathrm{Nd}$ & - & $\mathrm{Nd}$ & - & & \\
\hline Range & Nd-32 & - & Nd-1 & - & Nd-30 & - & & \\
\hline \multicolumn{7}{|c|}{$\mathrm{Cd}$} & \multirow{6}{*}{1.252} & \multirow{6}{*}{2.211} \\
\hline Number of detects & 38 & 10 & 15 & 5 & 20 & 9 & & \\
\hline Average & 234 & - & 171 & - & 318 & - & & \\
\hline Median & 124 & $\mathrm{Nd}$ & 101 & $\mathrm{Nd}$ & 174 & $\mathrm{Nd}$ & & \\
\hline $\mathrm{Sd}$ & 329 & - & 223 & - & 340 & - & & \\
\hline Range & $0-1844$ & Nd-78 & $7-797$ & Nd-142 & $7-975$ & Nd-296 & & \\
\hline \multicolumn{7}{|c|}{$\mathrm{Cr}$} & \multirow{6}{*}{0.975} & \multirow{6}{*}{1.004} \\
\hline Number of detects & 9 & 38 & 8 & 15 & 4 & 20 & & \\
\hline Average & - & 84 & 18 & 60 & - & 111 & & \\
\hline Median & $\mathrm{Nd}$ & 52 & 5 & 48 & $\mathrm{Nd}$ & 56 & & \\
\hline $\mathrm{Sd}$ & - & 142 & 27 & 38 & - & 179 & & \\
\hline Range & Nd-94 & $0-879$ & Nd-98 & $14-135$ & Nd-168 & $4-823$ & & \\
\hline \multicolumn{7}{|c|}{$\mathrm{Cu}$} & \multirow{6}{*}{2.188} & \multirow{6}{*}{9.697} \\
\hline Number of detects & 38 & 38 & 15 & 15 & 20 & 20 & & \\
\hline Average & 5972 & 4716 & 7040 & 3929 & 9116 & 4605 & & \\
\hline Median & 5264 & 3498 & 4625 & 3714 & 7919 & 3294 & & \\
\hline $\mathrm{Sd}$ & 3720 & 4286 & 6093 & 2372 & 5399 & 3808 & & \\
\hline Range & $2521-25791$ & $1303-26247$ & $2037-23438$ & $1670-10772$ & $2990-21676$ & 1718-19395 & & \\
\hline \multicolumn{7}{|c|}{$\mathrm{Hg}$} & \multirow{6}{*}{0.173} & \multirow{6}{*}{0.670} \\
\hline Number of detects & 30 & 37 & 11 & 13 & 17 & 20 & & \\
\hline Average & 95 & 90 & 42 & 128 & 325 & 78 & & \\
\hline Median & $53 \mathrm{~b}$ & 68 & $23 b$ & 123 & $167 \mathrm{a}$ & 67 & & \\
\hline $\mathrm{Sd}$ & 136 & 71 & 75 & 100 & 336 & 63 & & \\
\hline Range & Nd-565 & Nd-314 & Nd-278 & Nd-323 & Nd-1135 & $10-269$ & & \\
\hline
\end{tabular}


Table 1. Continued.

\begin{tabular}{|c|c|c|c|c|c|c|c|c|}
\hline \multicolumn{7}{|c|}{$\mathrm{Mn}$} & \multirow{6}{*}{1.681} & \multirow{6}{*}{0.732} \\
\hline Number of detects & 38 & 38 & 15 & 15 & 20 & 20 & & \\
\hline Average & 4317 & 237 & 3965 & 209 & 5323 & 236 & & \\
\hline Median & 4209 & 226 & 3797 & 222 & 4942 & 217 & & \\
\hline $\mathrm{Sd}$ & 1572 & 102 & 1454 & 74 & 2045 & 71 & & \\
\hline Range & $1476-8049$ & $74-705$ & $1984-7837$ & $73-341$ & $2381-9188$ & $159-417$ & & \\
\hline \multicolumn{7}{|c|}{$\mathrm{Pb}$} & \multirow{5}{*}{5.996} & \multirow{5}{*}{6.352} \\
\hline Number of detects & 6 & 3 & 2 & 2 & 5 & 2 & & \\
\hline Average & - & - & - & 218 & - & 2226 & & \\
\hline Median & $\mathrm{Nd}$ & $\mathrm{Nd}$ & $\mathrm{Nd}$ & $\mathrm{Nd}$ & $\mathrm{Nd}$ & $\mathrm{Nd}$ & & \\
\hline Range & Nd-13269 & Nd-969 & Nd-35452 & Nd-333 & Nd-13198 & Nd-4441 & & \\
\hline
\end{tabular}

Ppb ww - parts per billion on a wet weight basis; nd - not detectable

To compare differences among regions only data without non-detects values and those censored data with less than 50\% non-detects (Liver: $\mathrm{Cd}, \mathrm{Cu}, \mathrm{Hg}, \mathrm{Mn}$; muscle: $\mathrm{Cr}, \mathrm{Cu}, \mathrm{Hg}, \mathrm{Mn}$ ) was done by the nonparametric Kruskal-Wallis ANOVA with a subsequent post-hoc test using software Statistica [14]. Only significant differences are presented by boxplots.

\section{Results and Discussion}

Heavy metals, both essential and nonessential, and metalloids, are the most often analysed pollutants in wildlife. Wild animals chronically bioaccumulate trace elements generally without visible reaction to them, which would allow these organisms to be considered as suitable bioindicators [12]. Within the wildlife, avifauna, especially inland bird species, is the most intensively observed group of animals included in pollution testing and used as sentinels of environmental and human health [15]. Primarily birds of prey, situated at the top of the food chain, are at a higher risk of heavy metals accumulation in their tissues than other avian species [5].

Outgoing from numerous experimental and clinical studies, it is unambiguous that different trace elements are preferably deposited in different tissues at different rates. Although the liver and kidneys are the most frequently selected samples for biomonitoring of heavy metals and metalloids, muscles represent also an important source of information taking into account that various toxic elements are transferred between animals from different trophic levels via food chains. This is especially important in the case of mercury [16, 17]. Besides soft tissues some toxic elements, for instance, lead, are predominantly measured in bones [18]. On the other hand, metal concentrations in feathers are highly variable and depend on bird species and age, and for that reason some researcher state that feather samples have only low priority for ecotoxicological studies [19, 20].

In our, here presented study, trace element concentrations, including arsenic, cadmium, chromium, copper, mercury, manganese, and lead, were evaluated in livers and muscles in twelve species of birds of prey. The results expressed as average, median, standard deviation, and minimum and range values, are presented within the context of sampling regions (Table 1) and examined raptor species (Table 2). For four species (F. cherug, F. subbuteo, B. bubo and S. aluco), with the occurrence of one or two investigated individuals, only concentrations of tested elements without calculations are presented in Table 3.

\section{Copper $(\mathrm{Cu})$}

Within our study, copper was detected with the highest concentrations and ranged between 2037 and $25791 \mathrm{ppb}$ ww in liver samples, and from 1303 to $26247 \mathrm{ppb}$ ww in muscles (Table 1). Copper, an essential mineral element widely distributed in nature, is an important part of enzymes and proteins, and inevitable for the energy metabolism and defense system of animals. On the contrary, copper is used very often in agriculture as a component of pesticides and may be extremely toxic when ingested. The main anthropogenic $\mathrm{Cu}$-sources compromise pyrometallurgical industry, coal and oil combustion and steel and iron manufacturing [21]. Anyway, copper poisoning occurs especially in small ruminants and it is very rare in birds. For instance, the maximum tolerable level of cooper set by the National Research Council Committee (USA) is $100-250 \mathrm{mg} / \mathrm{kg}$ in poultry, but only $15 \mathrm{mg} / \mathrm{kg}$ in sheep [22]. No exact data are available on the toxicity of $\mathrm{Cu}$ in avian wildlife, but according to US Department of the Interior Guidelines, no-effect level of $\mathrm{Cu}$ in bird liver has been stated at $<60 \mathrm{mg} / \mathrm{kg}(60000 \mathrm{ppb} \mathrm{dw}$ ) [23]. In our study, the 


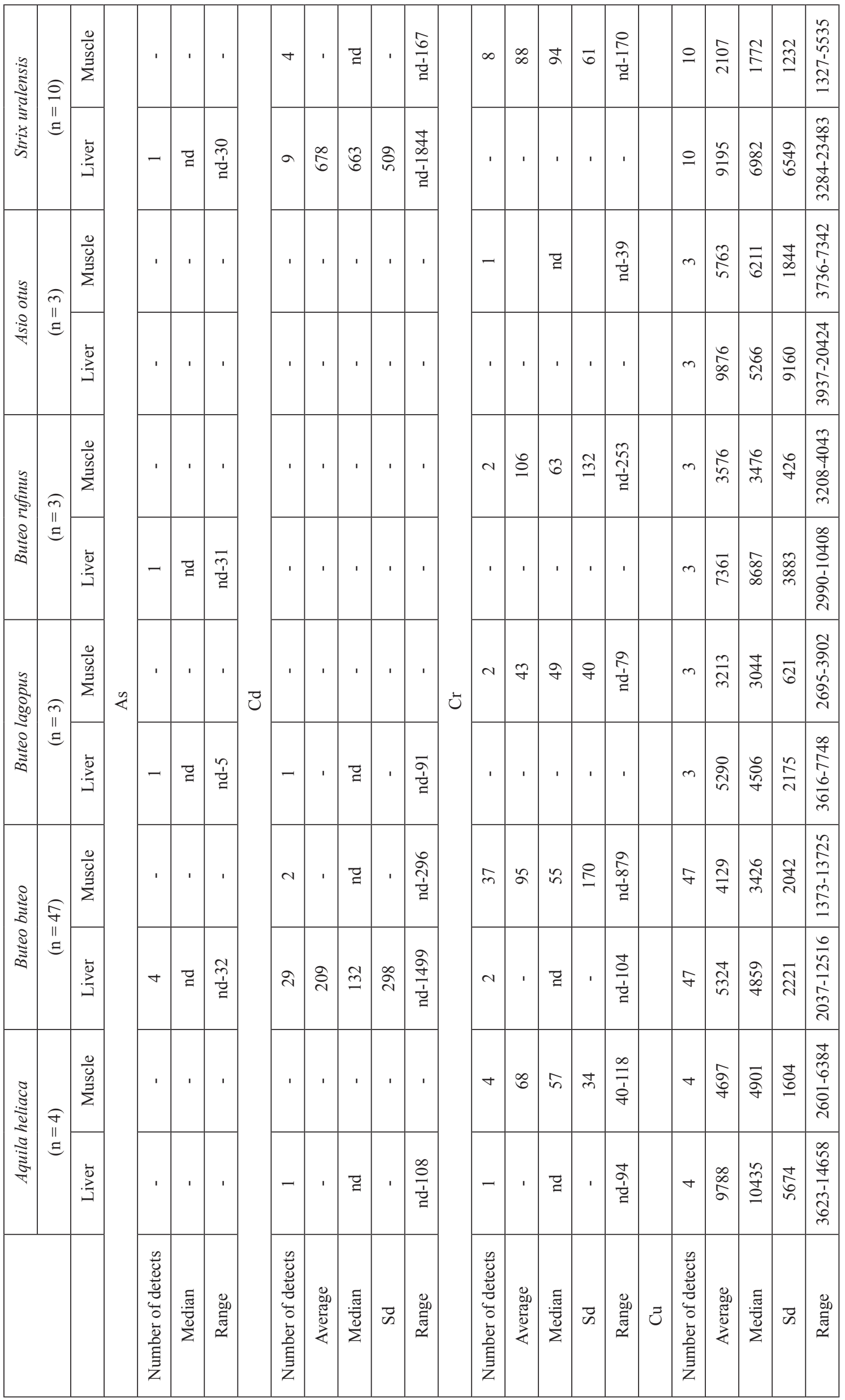




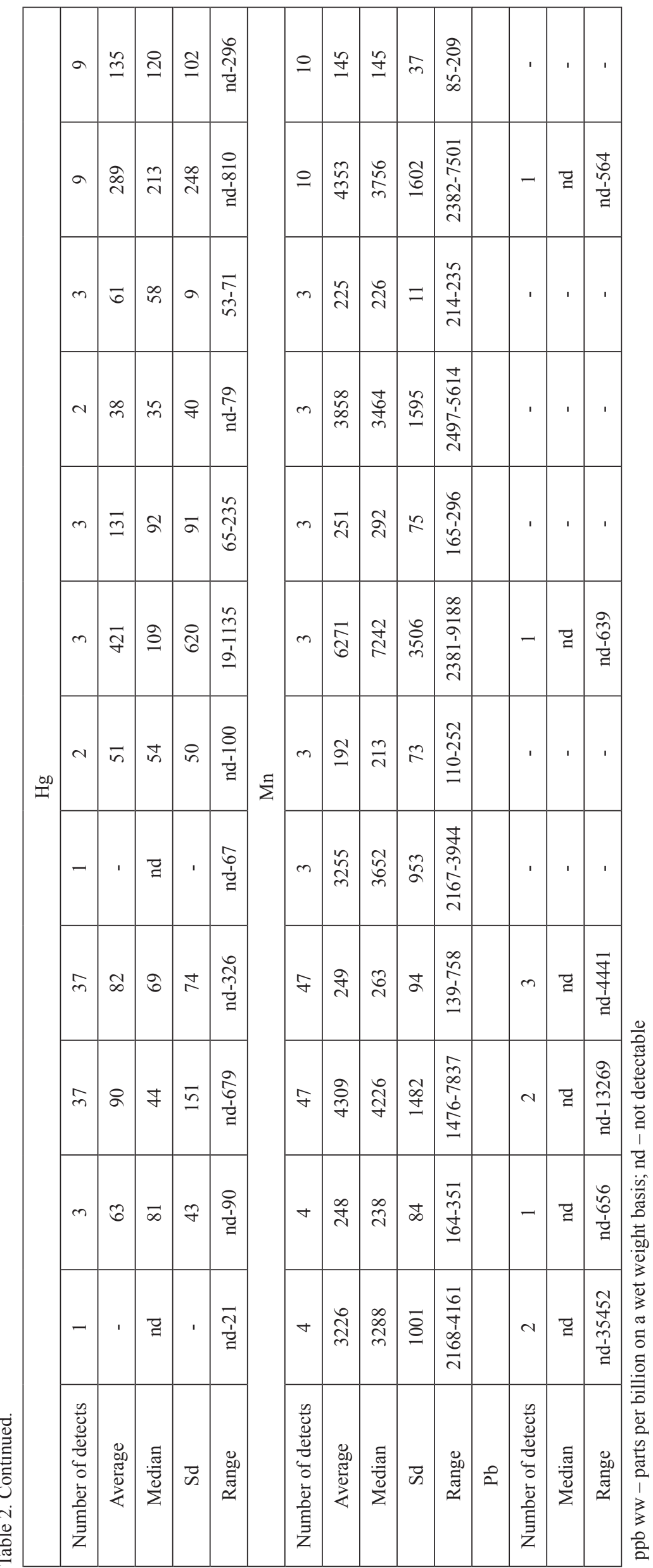


highest content of $\mathrm{Cu}$, overlapping this toxic threshold (20 $000 \mathrm{ppb}$ ww after conversion), was detected in muscle tissue of $F$. tinnunculus from Košice (Region II) with concentration $26247 \mathrm{ppb}$ ww (78 $741 \mathrm{ppb} \mathrm{dw}$ after conversion) and livers of B. bubo (25 $791 \mathrm{ppb} w w)$ from Region II, S. uralensis (23 $483 \mathrm{ppb} w \mathrm{w}$ ) from Region I, and $A$. gentilis and $S$. aluco from Region III (21 676 and 20424 ppb ww) (Tables 2 and 3). Based on results of several scientific studies, if was found that the average concentration of $\mathrm{Cu}$ in liver samples of birds of prey from Europe is circa $17 \mathrm{mg} / \mathrm{kg} \mathrm{dw}$ (5 $666 \mathrm{ppb}$ ww) with higher concentrations (more than $39 \mathrm{mg} / \mathrm{kg} \mathrm{dw}$ ) measured in common buzzards from Sicily [21]. A relatively high concentration of $\mathrm{Cu}$ in Slovak raptors is probably related to an occurrence of natural mineral deposits and long history of copper mining in Slovakia territory. At present, there are sixteen reserved deposits with reported $\mathrm{Cu}$ content, occurring mainly in Gemer and Spiš regions (regions II and III in our study) [24]. In these areas value of $\mathrm{Cu}$ concentration in the soil exceeds $150 \mathrm{mg} / \mathrm{kg}$ [25].

\section{Manganese (Mn)}

Manganese was the second-most detected element, though with high differences of concentrations recorded in livers 'samples (1 476-9 $188 \mathrm{ppb} \mathrm{ww}$ ) and muscles (73-705 ppb ww) (Table 1). Mn is essential for lipid metabolism, growth and reproduction system. On the other hand, during the last decades, a dramatic increase of $\mathrm{Mn}$ compounds in the atmosphere was measured. Most Mn emissions have a connection to the production of iron and steel. In Slovakia, the main source of Mn in the soil is U.S. Steel Company in the Košice region [11]. According to a review study, Mn concentration in European birds of prey varies between 5.3 to more than $12.0 \mathrm{mg} / \mathrm{kg}$ dw (1 766 and $4000 \mathrm{ppb}$ ww after conversion) in the liver and 0.5 to $3.5 \mathrm{mg} / \mathrm{kg} \mathrm{dw}$ (166 and $1166 \mathrm{ppb}$ ww after conversion) in muscles [26]. The maximum tolerable concentration of manganese in animals' diet is high. Manganese concentration in the liver above $70 \mathrm{ppm} \mathrm{dw}$ is considered as poisoning, but there are practically no studies that reported acute toxicosis [22].

\section{Mercury (Hg)}

The third metal found within the present study in the livers and muscles of birds of prey was mercury. Mercury together with cadmium and lead belongs to the group of particularly toxic metals. It is estimated that during the last 200 years, the concentration of $\mathrm{Hg}$ in nature has increased at least three times. Moreover, $\mathrm{Hg}$ released from natural and anthropogenic sources circulates in nature for a long time [27]. Proposed indicative liver $\mathrm{Hg}$ concentration associated with mortality in birds is $20 \mathrm{mg} / \mathrm{kg}$ ww (20 $000 \mathrm{ppb} \mathrm{ww}$ ) and with effect on reproductive system $2 \mathrm{mg} / \mathrm{kg}$ ww (2 000 ppb ww) [28]. Within our study, Hg was detected with the highest concentration in $S$. uralensis (Ural owl), with a median value of $213 \mathrm{ppb} w \mathrm{w}$ in livers and $120 \mathrm{ppb} \mathrm{ww}$ in muscles (Table 2). Comparing our results with other European researches, Kitowski et al. (2016) in Poland revealed a significantly higher average hepatic concentration of mercury in sparrowhawks (666 ppb ww), with the highest individual level of $3996 \mathrm{ppb} \mathrm{ww}$, if compared with kestrels (mean value $213 \mathrm{ppb} \mathrm{ww}$ ) and common buzzards (211 ppb ww) [29]. The authors, based on Redundancy analysis, showed that higher concentrations of mercury in livers of sparrowhawks are strongly dependent on the consummation of small granivorous birds (such as passerines) feeding on grains illegally treated with $\mathrm{Hg}$-based fungicide what was confirmed also in monitoring carried out in Hungary [30]. Another study conducted in Eastern Poland revealed Hg concentration in livers of white-tailed eagles (Haliaeetus albicilla) with mean values of 300 and 466 ppb ww in the northern and southern region, respectively [31]. In another study, carried out in Denmark, sparrowhawks and white-tailed eagles showed significantly higher mercury concentrations in their livers (average values of 1280 and $1210 \mathrm{ppb} w \mathrm{w}$ ) than other raptor species included in the research [32]. The highest individual level of mercury in our study (1 $135 \mathrm{ppb}$ ww) was measured in the liver of $B$. rufinus (long-legged buzzard) from a locality situated in the Slovak-Polish border and belonged in Region III (Table 2). Subsequent comparative analyses revealed significantly higher concentrations of mercury in surveyed Region III when compared with the other two sampling regions (Table 1). The territory of the Spiš region was evaluated as a region with extremely polluted soils [25]. It was an important gold and mercury mining area for centuries and it can be also the reason for the higher $\mathrm{Hg}$ concentration in some samples [33]. Recent monitoring confirmed also strong contamination of surface waters in Spiš with several metals including mercury, copper and lead [34]. Moreover, in this region besides anthropogenic influences also geochemical anomalies are conducive to higher content of heavy metals $[25,33]$.

\section{Cadmium $(\mathrm{Cd})$}

Another analyzed element, cadmium, was recorded with higher concentrations in the liver when compared with muscle samples. Generally, cadmium accumulation is greatest in the kidney, followed by the liver. On the other hand, muscles and bones accumulate cadmium only in low levels [22, 35]. The highest average concentration of $\mathrm{Cd}$ within our study (318 ppb ww) was measured in livers of raptors from Region III, although the highest individual level of this element (1 844 ppb ww; 5532 ppb dw after conversion) was found in Strix uralensis from Gemer (Region I) and in Buteo buteo (1 $499 \mathrm{ppb} w \mathrm{w}$ ) from Levice, the southern part of Central Slovakia (a nondescript region in our study) (Tables 1 and 2). Commonly, 
Cd concentration above $3 \mathrm{mg} / \mathrm{kg}$ dw (1 $000 \mathrm{ppb}$ ww) may indicate increased environmental exposure and considered to be a toxic threshold for birds [36]. From recently published summarized data, cadmium concentrations in livers of terrestrial avian species range widely between less than detection limit and more than $17000 \mathrm{ppb}$ dw [37]. For instance, in Poland, Kitowski et al. revealed mean concentration of $\mathrm{Cd}$ in livers of raptors ranged between 282 and $786 \mathrm{ppb} \mathrm{dw}$ with a maximum value of $3425 \mathrm{ppb}$ dw (1 $141 \mathrm{ppb}$ ww after conversion) in one common buzzard. Contrary, in other species of birds of prey much lower cadmium concentrations were measured [29, 31]. Also, in another recent study, Kanstrup et al. (2019) revealed significantly higher cadmium concentrations in livers of common buzzards and tawny owls than in kestrels, goshawks and white tailed eagles [32]. In Galicia, Spain, the mean hepatic concentration of $\mathrm{Cd}$ was highest in owls, with mean concentrations moved between 3381 and $5516 \mathrm{ppb} \mathrm{dw}$, and the highest rate of $39890 \mathrm{ppb} \mathrm{dw}$ (13 297 ppb ww after conversion) measured in one barn owl (Tyto alba), when compared with diurnal raptor species [38]. The most important factor influencing cadmium bioaccumulation in birds' tissues is the level of $\mathrm{Cd}$ contamination in their habitat. Higher concentrations of cadmium in the environment are usually recorded around the area with mining and smelting activities. Moreover, this soft metal can enter the environment through other anthropogenic sources - it is used in batteries, plastic stabilizers, fertilizers, etc. [22]. In Slovakia, several biomonitoring surveys focused on heavy metals, including cadmium, in the environment were carried out. According to these studies, high $\mathrm{Cd}$ concentrations were found almost all over the territory as a result of geological conditions characterized by the polymetallic ore formation process and metallurgical processing of these ores in the past. Besides, exceeded contents of $\mathrm{Cd}$ in the soil and water are the results of long-term phosphoric fertilizer application. As for $\mathrm{Cd}$ analysis, its concentrations in burden areas of Eastern Slovakia double exceeded the background values of the cambisols. Except for a few isolated samples, exceeding the content limit of cadmium was revealed in the mountainous area of Spiš and northern Gemer (Region III and I in our study) around the metallurgical and natural geochemical anomalies [10]. Another study, analyzing the soil-plant transfer of heavy metals, confirmed that the highest admissible amount of cadmium in feeds was exceeded in permanent grass of Spiš and the Slovenské Rudohorie Mountains [25]. It corresponds with our findings referring to the highest average hepatic Cd concentration in Region III and also the highest individual concentration in Gemer, Region I.

\section{Chromium $(\mathrm{Cr})$}

Considering chromium, it occurs naturally in trivalent form, which is generally recognized as an essential mineral, and in the more toxic hexavalent form used in the chemical industry and subsequently contaminating water, air, and soil. In the cells of bird, hexavalent $\mathrm{Cr}$ is reduced to trivalent $\mathrm{Cr}$, which produces highly toxic free radicals. Unlike cadmium predominantly concentrated in the avian liver and kidney, the highest percentage of chromium is cumulated in muscles followed by feathers with a much lower amount located in the liver [39]. Also, our results confirmed a much higher concentration of $\mathrm{Cr}$ in muscle tissues, ranged from 0 to $879 \mathrm{ppb} w \mathrm{w}$, when compared with liver samples. The highest average $\mathrm{Cr}$ concentration, $111 \mathrm{ppb}$ ww (333 ppb dw after conversion), was measured in muscle samples from Region III and the highest individual concentration, $879 \mathrm{ppb}$ ww (2 $637 \mathrm{ppb} \mathrm{dw}$ after conversion), was recorded in muscle sample of Buteo buteo from Region I (Tables 1 and 2). Despite a quite large number of studies that analyzed $\mathrm{Cr}$ bioaccumulation in avian species, only seldom birds of preys' muscles were examined [39]. Several studies were performed in the United States on bald eagles (Haliaeetus leucocephalus) where $\mathrm{Cr}$ cumulation in livers and brains was analyzed with the mean concentration values reached 1280 and $1470 \mathrm{ppb}$ dw, respectively (427 and $490 \mathrm{ppb}$ ww after conversion) [40]. In Poland, a wider spectrum of raptors species was investigated with $\mathrm{Cr}$ concentrations in livers ranged between 300 and $1220 \mathrm{ppb}$ dw (100 and $406 \mathrm{ppb}$ ww after conversion) [29, 31]. According to our knowledge, no formal reference values of $\mathrm{Cr}$ in tissues of wild birds were set. However, according to Wisconsin Veterinary Diagnostic Laboratory (WVDL), the normal values of chromium in avian liver moved between 170 and 1330 ppb dw (57 and 443 ppb ww) [41].

\section{Lead $(\mathrm{Pb})$}

Other analysed heavy metal, lead, revealed detectable concentrations only in fourteen livers and eight muscle samples. Liver concentrations of $\mathrm{Pb}$ over 6 ppm (6 $000 \mathrm{ppb} \mathrm{dw} ; 2000 \mathrm{ppb} \mathrm{ww}$ ) are considered as toxic threshold and external signs of poisoning may be present in affected animals. The concentration of $\mathrm{Pb}$ in avian liver above $30 \mathrm{ppm}$ (30 $000 \mathrm{ppb} \mathrm{dw}$; $10000 \mathrm{ppb} \mathrm{ww})$ reflects acute poisoning [42, 43]. Lead toxicosis is connected with cardiovascular, haematological and neurodevelopmental signs at low exposure levels, and renal, hepatic and immunological signs at higher doses or long exposure [22]. In our study, the hepatic $\mathrm{Pb}$ concentrations over the threshold of acute poisoning (10 $000 \mathrm{ppb} \mathrm{ww})$ were measured in three individuals: Aq. heliaca from Dolný Zemplín, Region II (35 $452 \mathrm{ppb} w \mathrm{w}), B$. buteo from Košice belonged to Region I (13 $269 \mathrm{ppb} w \mathrm{w}$ ) and A. gentilis from Spiš, Region III (13 $198 \mathrm{ppb}$ ww) (Tables 2 and 3). In other two individuals of $B$. buteo, both from Stará L'ubňa district situated on the SlovakPolish border (Region III), high concentrations of $\mathrm{Pb}$ in liver and muscle samples, 3164 and $4441 \mathrm{ppb}$ 
Table 3. Heavy metals concentrations (ng/g; ppb ww) in livers and muscles of individuals from species Accipiter gentilis, Falco cherug, Falco subbuteo, Falco tinnunculus, Bubo bubo and Strix aluco.

\begin{tabular}{|c|c|c|c|c|c|c|c|c|c|c|}
\hline & \multicolumn{2}{|c|}{$\begin{array}{l}\text { Accipiter gentilis } \\
\qquad(\mathrm{n}=2)\end{array}$} & \multirow{2}{*}{$\begin{array}{c}\begin{array}{c}\text { Falco } \\
\text { cherug } \\
(\mathrm{n}=1)\end{array} \\
\begin{array}{c}\text { Individual } \\
1\end{array}\end{array}$} & \multicolumn{2}{|c|}{$\begin{array}{l}\text { Falco subbuteo } \\
\qquad(\mathrm{n}=2)\end{array}$} & \multicolumn{2}{|c|}{$\begin{array}{l}\text { Falco tinnunculus } \\
\qquad(\mathrm{n}=2)\end{array}$} & \multicolumn{2}{|c|}{$\begin{array}{l}\text { Bubo bubo } \\
\quad(\mathrm{n}=2)\end{array}$} & \multirow{2}{*}{$\begin{array}{c}\begin{array}{c}\text { Strix } \\
\text { aluco } \\
(\mathrm{n}=1)\end{array} \\
\begin{array}{c}\text { Individual } \\
1\end{array}\end{array}$} \\
\hline & $\begin{array}{c}\text { Individual } \\
1\end{array}$ & $\begin{array}{c}\text { Individual } \\
2\end{array}$ & & $\begin{array}{c}\text { Individual } \\
1\end{array}$ & $\begin{array}{c}\text { Individual } \\
2\end{array}$ & $\begin{array}{c}\text { Individual } \\
1\end{array}$ & $\begin{array}{c}\text { Individual } \\
2\end{array}$ & $\begin{array}{c}\text { Individual } \\
1\end{array}$ & $\begin{array}{c}\text { Individual } \\
2\end{array}$ & \\
\hline \multicolumn{11}{|c|}{ As } \\
\hline Liver & nd & nd & nd & nd & nd & nd & nd & nd & nd & 69 \\
\hline Muscle & nd & nd & nd & nd & nd & nd & nd & nd & nd & nd \\
\hline \multicolumn{11}{|c|}{$\mathrm{Cd}$} \\
\hline Liver & 574 & 184 & nd & 88 & 164 & 354 & 14 & 23 & 211 & 206 \\
\hline Muscle & 6 & 20 & nd & nd & 17 & nd & nd & nd & nd & nd \\
\hline \multicolumn{11}{|c|}{$\mathrm{Cr}$} \\
\hline Liver & nd & nd & nd & nd & 50 & nd & 168 & nd & nd & nd \\
\hline Muscle & 29 & 90 & 118 & 51 & 16 & 14 & 43 & 81 & 74 & 87 \\
\hline \multicolumn{11}{|c|}{$\mathrm{Cu}$} \\
\hline Liver & 4995 & 21676 & 5364 & 13444 & 8306 & 5472 & 9445 & 25791 & 5324 & 20424 \\
\hline Muscle & 2788 & 2812 & 4450 & 10772 & 4232 & 4626 & 26247 & 1670 & 13333 & 1303 \\
\hline \multicolumn{11}{|c|}{$\mathrm{Hg}$} \\
\hline Liver & 371 & 357 & nd & 489 & 848 & 74 & nd & 564 & 403 & 42 \\
\hline Muscle & 323 & 314 & nd & 124 & 149 & 54 & 139 & 165 & 173 & 47 \\
\hline \multicolumn{11}{|c|}{$\mathrm{Mn}$} \\
\hline Liver & 3546 & 8637 & 2116 & 8036 & 4092 & 6218 & 7532 & 8049 & 4992 & 9240 \\
\hline Muscle & 203 & 190 & 270 & 341 & 271 & 253 & 227 & 73 & 74 & 163 \\
\hline \multicolumn{11}{|c|}{$\mathrm{Pb}$} \\
\hline Liver & nd & 13198 & nd & nd & nd & nd & nd & nd & nd & nd \\
\hline Muscle & 333 & nd & nd & nd & nd & nd & nd & nd & nd & nd \\
\hline
\end{tabular}

ppb ww - parts per billion on a wet weigh basis; nd - not detectable

ww, respectively, were found. A similar study from Eastern Poland revealed in livers of examined B. buteo $(\mathrm{n}=31)$ mean lead concentration value of $1217 \mathrm{ppb}$ $\mathrm{dw}$ (406 ppb ww after conversion) with the maximum rate of $15310 \mathrm{ppb}$ (5 $103 \mathrm{ppb}$ ww after conversion)

[29]. Another study from Poland focused on the detection of lead in white-tailed eagle, revealed high differences of median $\mathrm{Pb}$ liver concentration between the northern and southern area of Eastern Poland with measured values of $36900 \mathrm{ppb} \mathrm{dw}$ (12300 ppb ww) and $700 \mathrm{ppb} \mathrm{dw}$ (233 ppb ww), respectively. Within this study very high individual concentration of $\mathrm{Pb}$, $188600 \mathrm{ppb}$ dw (62 $867 \mathrm{ppb}$ ww after conversion), was confirmed [31]. Kanstrup et al. (2019) found out significantly higher lead concentrations in common buzzards than in kestrels, though an extreme value of lead concentration (149 $000 \mathrm{ppb} \mathrm{dw} ; 49667 \mathrm{ppb}$ ww) was measured in the kestrel shot at the airport in Jutland, Denmark [32]. Ingested shots through the carrions and games seem to be the main source of lead poisoning in raptors, especially in buzzards and eagles that catch a wide range of prey $[44,45]$. Also, the latest European study focused on biomonitoring of terrestrial environment for pollutants confirmed that common buzzard and golden eagle (Aquilla chrysaetos) proved the most suitable sentinel for lead [46]. Additionaly, Monclús et al. (2020) in their research revealed a seasonal peak in blood lead concentrations related to hunting season [47].

Currently, according to Agency for Toxic Substances and Disease Registry (ATSDR) Substance Priority List, lead is considered the second most dangerous environmental poison [48]. Atmospheric lead is a result of industrial and traffic-related emissions. According to the World Health Organisation (WHO), the average concentration of $\mathrm{Pb}$ in the air around large European 
cities ranged from 0.5 to $3.0 \mu \mathrm{g} / \mathrm{m}^{3}$. The most leadpolluted air is found around mines and metal smelters, where it can reach $12 \mu \mathrm{g} / \mathrm{m}^{3}$ [49]. In Slovakia, extremely high content of $\mathrm{Pb}$ was detected also in soils around agglomeration of Krompachy, Spiš region, as the result of solid pollutants emitted from the chimneys in the pit furnaces [10]. High lead concentrations were measured also in soils of the Volovské Mountains in the border of Gemer and Spiš regions, and an important $\mathrm{Pb}$ reserved deposit is situated in Dolný Zemplín [24]. Even though our results disclosed high $\mathrm{Pb}$ concentrations in raptors tissues from all sampling regions, the values exceeded 2000 and even $10000 \mathrm{ppb}$ ww point to probability of acute poisoning through lead shots ingestion.

\section{Arsenic (As)}

Only eight liver samples showed the presence of very small concentrations (from 1 to $69 \mathrm{ppb} \mathrm{ww}$ ) of metalloid arsenic. Arsenic was detected only in raptors from the genus Buteo (B. buteo, B. rufinus, B. lagopus) and Strix (S. uralensis and Strix aluco) (Tables 2 and 3). None of the muscle samples was tested positive for this element. Also, studies across Europe revealed that in most cases concentration of As in animal tissues was lower than the detection limit [50]. Contrary, in birds of prey from Galicia, Northern Spain, high mean levels of hepatic As concentrations were measured and ranged between $1212 \mathrm{ppb}$ dw (404 ppb ww after conversion) and $6878 \mathrm{ppb} \mathrm{dw}$ (2 $293 \mathrm{ppb}$ ww after conversion) [38].
Generally, As in environment occurs with higher concentration in geographical regions characterized by strong volcanic activity. The Land Use/Land Cover Area Frame Survey (LUCAS) performed in European Union showed that in more than $95 \%$ of topsoil samples As was detected with concentration below $20 \mathrm{mg} / \mathrm{kg}$ and a high portion of samples contain As bellow the limit of detection [33]. In Slovakia, the highest As levels, connected to metal purification industry and fossil fuel combustion, were detected in the Košice region [34].

\section{Regional Differences}

Regarding geographical differences, in birds of prey's livers from Region III Kruskal-Wallis Anova $(\mathrm{H}(2, \mathrm{~N}=73)=10.06, \mathrm{p}=0.01)$ and the subsequent posthoc test revealed a significantly higher concentration of mercury when compared with Region I $(p=0.05)$ and Region II $(p=0.05)$. Additionally, differences among the three regions were confirmed for copper from the liver $(\mathrm{H}(2, \mathrm{~N}=73)=6.85, \mathrm{p}=0.03)$, but without significant differences between couples of regions. Also, the highest average and median values concerning liver concentrations of cadmium and manganese and muscle concentrations of chromium were measured in samples originated Region III. Significant differences in the distribution of $\mathrm{Hg}$ and $\mathrm{Cu}$ in the liver among regions are clear also from Fig. 2.

Region III (Spiš and Tatry region) represents an area located in the north-eastern and north-central parts of
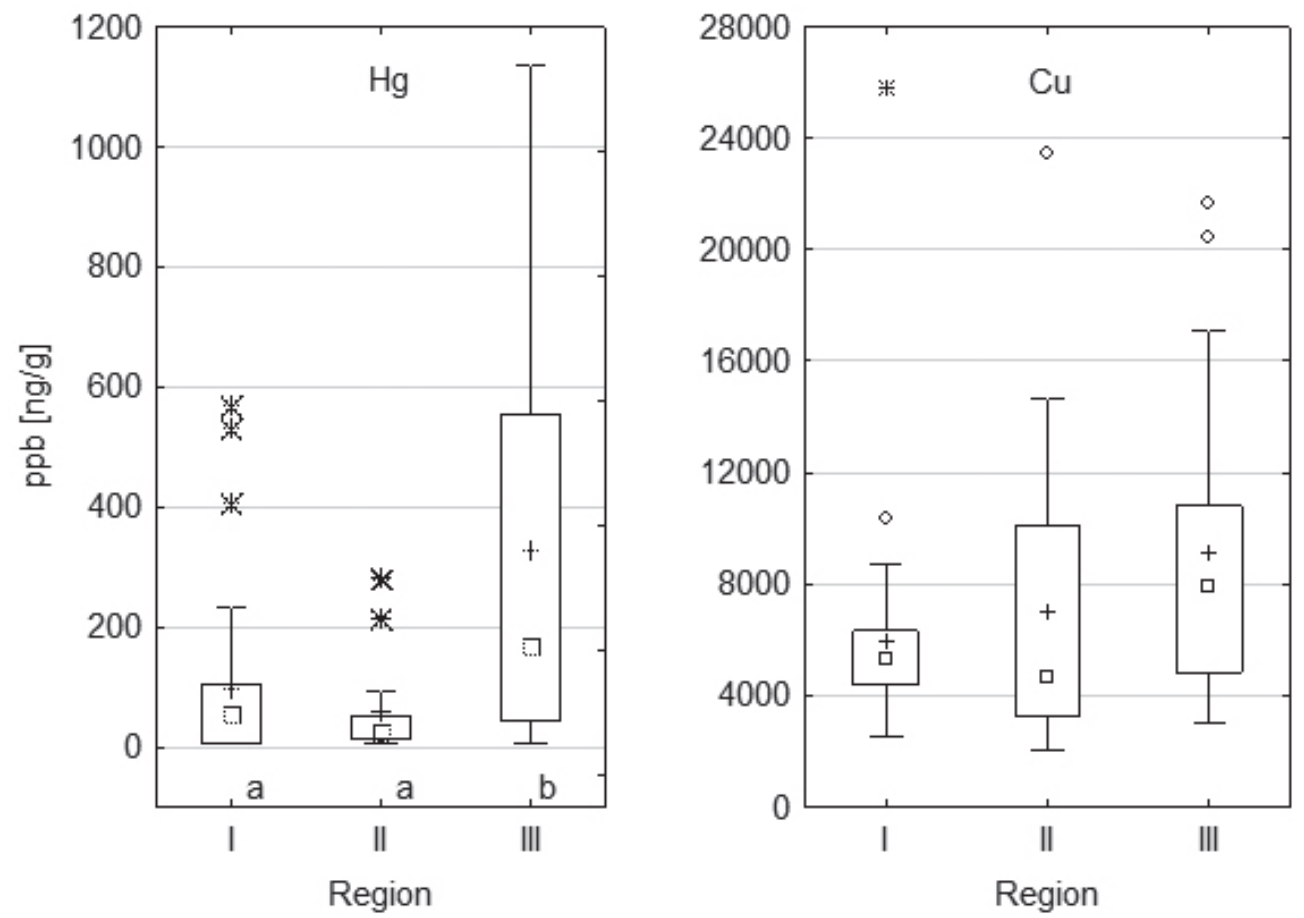

Fig. 2. The boxplots of $\mathrm{Hg}$ and $\mathrm{Cu}$ distribution in liver samples with significant differences among regions. Significant differences $(\mathrm{p}=0.05)$ confirmed by post-hoc test after Kruskal Wallis ANOVA between couples of regions only for Hg are marked by different lowercase letters. Square - median, box - 25\%-75\%, whiskers - interquartile range, circle - outliers, star - extremes, plus - average. 
Slovakia bordering Poland (Fig. 1). Especially in the Spiš region, the most of heavy metal-loaded habitats are located. These habitats were created as a consequence of the long-term history of pyrite, copper, and mercury mining and smelting. The soils of these areas are ranked among the most contaminated with mercury, arsenic, copper, zinc and lead [10]. Besides, the occurrence of natural endogenous geochemical anomalies is particularly prevalent in mountainous zones of this region $[25,33]$.

\section{Conclusion}

Here presented study represents the first published results of toxic elements biomonitoring, including arsenic (As), cadmium (Cd), chromium (Cr), copper $(\mathrm{Cu})$, mercury $(\mathrm{Hg})$, manganese $(\mathrm{Mn})$ and lead $(\mathrm{Pb})$, in birds of prey species from Slovakia. The results revealed that hepatic concentration of $\mathrm{Cu}$ and $\mathrm{Cd}$ overlapped defined toxic thresholds in several individuals from all sampling regions. Moreover, $\mathrm{Pb}$-analyses confirmed concentration rates suggesting acute poisoning (over $10000 \mathrm{ppb} w w)$ Aq. heliaca, B. buteo, and A. gentilis, each of them originated in a different region. Subsequent comparative analyses revealed significantly higher concentrations of mercury in surveyed Spiš and Tatry Region when compared with the other two regions. It is worth noting that the whole territory of this region is covered by national parks (High and Low Tatra national parks, Pieniny National Park, and Slovenský raj National Park) and protected areas and several European Important Bird Areas occurred there. The area provides suitable conditions for a high diversity of bird species; it is an important nesting site for forest birds, birds of prey and forest owls. Nevertheless, from a glance at wildlife health and ecology, it is necessary to mention that the whole region is used primarily for tourism and recreational activities. Additionally, the nearly whole area is used for foresting and hunting purposes and a quite large area of military training zone is located here. All these activities lead to an excessive disturbance and threat to the birds. Moreover, considering rich mining and smelting history and also the existence of natural geochemical anomalies, toxic elements biomonitoring should continue in this area.

\section{Acknowledgement}

This study was financially supported by VEGA scientific grant no. 1/0043/19.

\section{Conflict of Interest}

The authors declare they have no conflict of interest.

\section{References}

1. KALISIŃSKA E. Human population increase and changes in production and usage of trace elements in the twentieth century and first decades of the twenty-first century. In Mammals and Birds of Trace Element Contaminations in Terrestrial Environment (Elzbieta Kalisińska ed.). Springer International Publishing, Cham, Switzerland, ISBN 978-3030-00119-3, 3, 2019.

2. BANÁSOVÁ V., ČIAMPOROVÁ M., NADUBINSKÁ M. Heavy metal localities and their vegetation in Slovakia. Available online: http://www.metaltolerantplants.sav.sk/ Publications/HM_sites_Slovakia.pdf (April 6 $6^{\text {th }}$ 2021), 2007.

3. Bond DPG, Grasby SE On the causes of mass extinctions. Palaeogeogr Palaeoclimatol 478, 3, 2016.

4. ANSARA-ROSS T.M., ROSS M.J., WEPENER V. The use of feathers in monitoring bioaccumulation of metals and metalloids in the South African endangered African grasowl (Tyto capensis). Ecotoxicology 22 (6), 1072, 2013.

5. GÓMEZ-RAMÍREZ P., SHORE R.F., VAN DEN BRINK N.W., VAN HATTUM B., BUSTNES J.O., DUKE G., FRITSCH C., GARCÍA-FERNÁNDEZ A.J., HELANDER B.O., JASPERS V, KRONE O., MARTÍNEZ-LÓPEZ E., MATEO R., MOVALLI P., SONNEV C. An overview of existing raptor contaminant monitoring activities in Europe. Environment International, 67, 12, 2014.

6. RYBANIČ R., ŠUTIAKOVÁ T., BENKO Š. (eds.) Important Bird Areas of European Union Importance in Slovakia. Society for the Protection of Birds in Slovakia, Bratislava. 2004, ISBN-80-969078-0-8, 220 pp, 2004.

7. DRAVECKÝ M., GUZIOVÁ Z. A preliminary overview of monitoring for raptors in the Slovak Republic. Acrocephalus 33 (154/155), 261, 2012.

8. Raptor protection of Slovakia. Available online: https:// www.dravce.sk/web/index.php/en/ (April $6^{\text {th }}$ 2021).

9. Statistical office of the Slovak Republic. Regional statistics. Available online: https://slovak.statistics.sk/wps/portal/ext/ themes/regional (April $6^{\text {th }}$ 2021).

10. VILČEK J., HRONEC O., TOMÁŠ J. Risk Elements in Soils of Burdened Areas of Eastern Slovakia Pol J Environ Stud 21 (5), 1429, 2012.

11. Environment of the Slovak Republic in Focus (Lieskovská, Hericová, eds). Ministry of Environment of the SR, Slovak Environment Agency, pp. 89. ISBN: 978-80-8213-009-9. Available online: https://www.enviroportal.sk/uploads/ report/10422.pdf (April 6 $\left.6^{\text {th }} 2021\right) 2019$.

12. KALISIŃSKA E. (201) Endothermic Animals as Biomonitors of Terrestrial Environments. In Mammals and Birds of Trace Element Contaminations in Terrestrial Environment (Elzbieta Kalisińska ed.). Springer International Publishing, Cham, Switzerland, ISBN 978-3030-00119-3, pp. 21-53.

13. Data Quality Assessment: Statistical Methods for Practitioners EPA QA/G-9S. Environmental Protection Agency, Office of Environmental Information Washington, DC 20460, EPA/240/B-06/003, February 2006 United States. Available online: https://www.epa.gov/sites/ production/files/2015-08/documents/g9s-final.pdf (April $6^{\text {th }}$ 2021) 2006.

14. StatSoft, Inc STATISTICA (data analysis software system), version 12.0. www.statsoft.com, 2013.

15. KECK F. Sentinels for the environment. China Perspect 2 , 43, 2015. 
16. KALISINSKA E., LANOCHA-ARENDARCZYK N., KOSIK-BOGACKA D.I., BUDIS H., PILARCZYK B., TOMZA-MARCINIAK A., PODLASINSKA J., CIESLIK L., POPIOLEK M., PIROG A., JEDRZEJEWSKA E. Muscle mercury and selenium in fishes and semiaquatic mammals from a selenium-deficient area. Ecotoxicol Environ Saf 136, 24, 2017.

17. KALISINSKA E., LANOCHA-ARENDARCZYK N., KOSIK-BOGACKA D.I. Mercury, Hg. In Mammals and Birds of Trace Element Contaminations in Terrestrial Environment (Elzbieta Kalisińska ed.). Springer International Publishing, Cham, Switzerland, ISBN 978-3030-00119-3, 593, 2019.

18. DEMESKO J., MARKOWSKI J., SŁABA M., HEJDUK J., MINIAS P. Age-related patterns in trace element content vary between bone and teeth of the European roe deer (Capreolus capreolus). Arch Environ Contam Toxicol 74, 330, 2018.

19. ACKERMAN J.T., EAGLES-SMITH C.A., HERZOG M., HARTMAN C., PETERSON S., EVERS D.C. et al Avian mercury exposure and toxicological risk across western North America: a synthesis. Sci Total Environ 568, 749, 2016.

20. RENDÓN-LUGO A.N., SANTIAGO P., PUENTE-LEE I., LEÓN-PANIAGUA L. Permeability of hair to cadmium, copper and lead in five species of terrestrial mammals and implications in biomonitoring. Environ Monit Assess 189, 640, 2017.

21. LANOCHA-ARENDARCZYK N., KOSIK-BOGACKA D.I. Copper, $\mathrm{Cu}$, In Mammals and Birds of Trace Element Contaminations in Terrestrial Environment (Elzbieta Kalisińska ed.). Springer International Publishing, Cham, Switzerland, ISBN 978-3-030-00119-3, 125, 2019.

22. NRC (National Research Council) Mineral tolerance of animals. National Academic Press, Washington, D.C., USA, 511, 2005

23. US Department of the Interior Guidelines for interpretation of the biological effects of selected constituents in biota, water, and sediment. National Irrigation Water Quality ProgramInformation Report 3, 198, 1998.

24. BALÁŽ P. Review of reserved deposit of metals in Slovakia. Slovak Geol Mag 15 (2), 31, 2015.

25. KOBZA J. Soil and plant pollution by potentially toxic elements in Slovakia. Plant Soil Environ 51 (6), 243, 2005.

26. KALISINSKA E., BUDIS H. Manganese, Mn. In Mammals and Birds of Trace Element Contaminations in Terrestrial Environment (Elzbieta Kalisińska ed.). Springer International Publishing, Cham, Switzerland, ISBN 978-3030-00119-3, 213, 2019.

27. HOROWITZ H.M., JACOB D.J., AMOS H.M., STREETS D.G., SUNDERLAND E.M. Historical mercury releases from commercial products: global environmental implications. Environ Sci Technol 48, 10242, 2014.

28. SHORE R.F., PEREIRA M.G., WALKER L.A., THOMPSON D.R. Mercury in nonmarine birds and mammals. In Environmental contaminants in biota (Beyer WN, Meador JP eds). CRC Press, Boca Raton, Florida, ISBN: 978-1-4200-8405-4, 609, 2011.

29. KITOWKSI I., SUJAK A., WIĄCEK D., STROBEL W., KOMOSA A., STOBIŃSKI M. Heavy metals in lives of raptors from Eastern Poland - the importance of diet composition. Belg J Zool 146 (1), 3, 2016.

30. GRÚZ A., DÉRI J., SZEMERÉDY G., SZABÓ K., KORMOS É., BARTHA A., LEHEL J., BUDAI P. Monitoring of heavy metal burden in wild birds at eastern/ north-eastern part of Hungary. Environ Sci Pollut Res 25 (7), 6378, 2018.

31. KITOWSKI I., JAKUBAS D., WIĄCEK D., SUJAK A. Concentrations of lead and other elements in the liver of the white-tailed eagle (Haliaeetus albicilla), a European flagship species, wintering in Eastern Poland. Ambio 46 (8), 825, 2017.

32. KANSTRUP N., CHRIÉL M., DIETZ R., SØNDERGAARD J., BALSBY T., SONNE C. Lead and Other Trace Elements in Danish Birds of Prey. Arch Environ Contam Toxicol 77, 359, 2019.

33. TÓTH G., HERMANN T., SZATMÁRI G., PÁSZTOR L. Maps of heavy metals in the soils of the European Union and proposed priority areas for detailed assessment. Science of The Total Environment 565, 1054, 2016.

34. HRUŠKOVÁ T. The most important pollutants of eastern Slovakia waters. J Microbiol Biotech Food Sci 4 (2), 112, 2014.

35. DURKALEC M., SZKODA J., KOŁACZ R., OPALINSKI S., NAWROCKA A., ZMUDZKI J. Bioaccumulation of lead, cadmium and mercury in roe deer and wild boars from areas with different levels of toxic metal pollution. Int J Environ Res 9, 205, 2015.

36. SCHEUHAMMER A.M. The chronic toxicity of aluminium, cadmium, mercury, and lead in birds: a review. Environ Pollut 46 (4), 63, 1987.

37. TOMZA-MARCINIAK A., PILARCZYK B., MARCINIAK A., UDALA J., BAKOWSKA M., PILARCZYK R. Cadmium, Cd. In Mammals and Birds of Trace Element Contaminations in Terrestrial Environment (Elzbieta Kalisińska ed.). Springer International Publishing, Cham, Switzerland, ISBN 978-3-030-00119-3, 483, 2019

38. PÉREZ-LÓPEZ M., HERMOSO D.E., MENDOZA M., SOLER RODRÍGUEZ F. Heavy metal $(\mathrm{Cd}, \mathrm{Pb}, \mathrm{Zn})$ and metalloid (As) content in raptor species from Galicia (NW Spain). Ecotoxicol Environ Saf 70, 154, 2008.

39. KOŚLA T., LASOCKA I., KOŁNIERZAK M. Chromium, Cr. In Mammals and Birds of Trace Element Contaminations in Terrestrial Environment (Elzbieta Kalisińska ed.). Springer International Publishing, Cham, Switzerland, ISBN 978-3-030-00119-3, 57, 2019.

40. NAM D.-H., RUTKIEWICZ J., BASU N. Multiple metals exposure and neurotoxic risk in bald eagles (Haliaeetus leucocephalus) from two Great Lakes states. Environ Toxicol Chem 31, 623, 2012.

Wisconsin Veterinary Diagnostic Laboratory (WVDL), Normal Range Values for WVDL Toxicology. Available online: https://www.yumpu.com/en/document/ $\mathrm{read} / 52919318 /$ normal-range-values-for-wvdl-toxicology

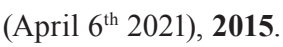

41. HERRING G., EAGLES-SMITH C.A., BUCK J.A. Characterizing golden eagle risk to lead and anti-coagulant rodenticide exposure. J Raptor Res 51, 273, 2017.

42. BARANOWSKA-BOSIACKA I., KORBECKI J., MARCHLEWICZ M. Lead, Pb. In Mammals and Birds of Trace Element Contaminations in Terrestrial Environment (Elzbieta Kalisińska ed.). Springer International Publishing, Cham, Switzerland, ISBN 978-3-030-00119-3, 563, 2019.

43. BELLINGER D.C.J, BURGER T.J., CADE D.A., CORY-SLECHTA M., FINKELSTEIN H., HU M. et al. Health risks from lead-based ammunition in the environment. Environ Health Perspect 121, A178-A179, 2013. 
44. PAIN D.J., MATEO R., GREEN R.E. Effects of lead from ammunition on birds and other wildlife: A review and update. Ambio 48 (9), 935, 2019.

45. BADRY A., KRONE O., JASPERS V.L.B., MATEO R., GARCÍA-FERNÁNDEZ A., LEIVITS M., SHORE R.F. Towards harmonisation of chemical monitoring using avian apex predators: Identification of key species for panEuropean biomonitoring. Sci Total Environ 731, 139198, 2020.

46. MONCLÚS L., SHORE R.F., KRONE O. Lead contamination in raptors in Europe: A systematic review and meta-analysis. Sci Total Environ 748, 141437, 2020.
47. Agency for Toxic Substances and Disease Registry. The ATSDR 2019 Substance Priority List. Available online: https://www.atsdr.cdc.gov/spl/index.html 2019.

48. WHO Regional publications, European series. Inorganic pollutants. Lead 91:1-17. Air quality guidelines for Europe; second edition (WHO regional publications. European series; No. 91) SBN 928901358 3, pp 288 ext editing: Frank Theakston, 2020.

49. BINKOWSKI L. Arsenic, As. In Mammals and Birds of Trace Element Contaminations in Terrestrial Environment (Elzbieta Kalisińska ed.). Springer International Publishing, Cham, Switzerland, ISBN 978-3-030-00119-3, 463, 2019. 